\title{
Career Guidance Program to Raise the Employability Skills of Vocational High School (SMK) Students
}

\author{
M. Amirullah \\ Indonesia University of Education, Bandung, Indonesia \\ e-mail: amirullah14@student.upi.edu
}

\begin{abstract}
Employability skills is a non-technical skill required by individuals who want to enter the world of work. Employability skills can support the various activities and career development of a person in the world of work, and giving more adventages for the person and for the work environment. Elements of employability skills according to the ILO are: a) basic skills: communication, b) thinking skills: problem solving and innovative thinking, and c) affective skills: responsibility, positive attitude towards work, efficiency, interpersonal skills, teamwork, self-confidence, positive self-image, Adaptability, flexibility, enthusiasm, motivation, discipline, self-management, tidy, honesty, integrity, and the ability to work unattended. Employability skills for Vocational High School (SMK) students is very important, so that need to be developed through the career guidance services
\end{abstract}

\section{Keywords: Employability skills, Vocational High Schools, Career Guidance}

\section{INTRODUCTION}

The current job market requires skilled people who not only rely on technical skills, but also on cognitive skills and non-cognitive abilities notably called as life skills [1]. Employability skills are one among the entire lifeskills that are mainly required. These skills are non-technical skills which are equipped for individuals who need to enter on job entry in order to survive in the world of work, to develop a career in the workplace in which they are involved in, and to develop themselves in the type of other works [2].

In the increasing needs of the workforce against the employability skills, there is an interesting evidence showing that there are still graduates of higher education who have a weakness in terms of employability skills [3]. In addition they feel that they obtain unadequate skills during learning in colleges. Thus, they are less confident to compete in the workplace even though they are highly keen on the other types of skills [4]. In contrast, there is also a difference of views between employers and students about the needed skills in the workforce [5]. This needs to be addressed well because the weakness in terms of employability skills might be one of the causes that the graduates from medium and high education are less received in the workplace [2].
Employability skills possessed by a person has a positive correlation with the career adaptability [6] and support the ability of coorporating with others in workplace [7]. This disclosed a logical reason of the importance of employability skills to help supply the graduates of universities and vocational schools to be accepted in the workplace. This can be seen based on the results of the survey of NACE in 2002 to 457 leaders of companies about the most important quality demanded towards an employee, the row results are as follows the ability to communicate, honesty and integrity, the ability to cooperate, interpersonal skills, ethical behavior, motivation and initiative, adaptability, analytical power, computer capabilities, the organization abilities, detail-oriented, leadership, confidence, friendly, polite, thoughtful, humorous, creative, GPA, and entrepreneurship capabilities [8].

Employability skills become the requirements desired in the workforce against the prospective workers [9]. The workforce in the field of industries in Malaysia, Japan, Singapore, and Hong Kong strongly highly emphasize on the importance of employability skills [10]. In the context of Indonesia, the discussion of employability skills were recently crowded around the 2000's marked by thunderstorms, and the decision of the Minister of manpower and transmigration (Menakertrans) in 2003 about The determination of the Standard of national Work competence in Indonesia [11]. 
Irma revealed that entrepreneurs in Indonesia also disclosed an important valuation on employability skills [12]. There are 20 kinds of the basic skills required by the industry in Indonesia, and honesty occupies the highest position, followed by ethics in work, responsibility, discipline, and upholding safety in work [13]. The entrepreneurs expect that employability skills on university graduates should be on high level so that graduates are keen to compete in the global market competition [14]. Employability skills are not only required for university graduates, but also for the work force who are from senior high school graduates [15].

Unfortunately, higher education institutions and secondary schools have not been able to equip the graduates optimally in accordance with expectations. One of the constraints in providing employability skills provision to students is the teachers' low level of understanding about it and the absence of a clear curriculum that set out the employability skills [12]. Moreover, it is because there has not been regulation governing what employability skills which must be owned by the college graduates [16]. This often gives rise to a different perspective of employability skill needs given by education world with the needs required by the workforce [17] [18]. Therefore it is important for the stakeholders of education world to give more attention in the development of employability skills for the participants or students and the notable Alumni [19]. Moreover, it is also necessary to build a good integration between the world of work with the education world [20] [21], as well as providing a non-technical skill description that must be prepared by the students [22] [23]. The formulated purpose of this is to prepare the graduates to have a good readiness in entering into job entry after his studies. Employability skills development also requires the involvement of the Government and enterpreneurs to clarify actual softskills prioritized in the workplace [24].

A discussion about the importance of employability skill has been widely discussed at the college level, however, the essential point is not only on colleges that need to ensure employability skills, but also at the level secondary education notably in SMK in which it is indeed prepared to have proficiency in the working world. Among the goals of SMK establishment listed in Act No. 20 of 2003 is to develop the potential students to be citizens who have the precious, healthy, learned, accomplished, creative, independent, democratic and accountable.

Permendiknas No. 22 in 2006 disclosed that vocational education aims to improve intelligence, knowledge, personality, attitudes, and noble, as well as the skills of learners to live independently and follow further education in accordance with the specific major. Unfortunately the implementation of goals of SMK's existence proved to be not reached optimally. The evidence shows that the Central Bureau of statistics alerts data that the largest unemployment rates in Indonesia per February 2016 are SMK graduates. From the total unemployment of 7.02 million SMK people donate the largest numbers $(9.84 \%)$. In addition to the employment field factor, the quality of education also triggers the its height because education world has not exactly responded what things need to be prepared by its graduates to enter the workforce [25].

The high number of unemployment figures on SMK level essentially indicates there are less things in preparing SMK graduates to enter in the workplace, one fundamental preparation is employability skills [26]. Guidance and counseling as part of an inseparable in the process of education must take a leading role in preparing SMK students to have work qualification. In this case, nontechnical skills or employability skills are notably required for the success in the world of work. By owning understanding and supply employability skills, it is demanded that the SMK graduates will be much better to be able to demonstrate the competitive power in the workplace.

It particularly needs a good integration of efforts between the world of work and the education world to enhance the SMK students' employability skills. Integrating the workforce and education, one of which can be done in a way and dispersed the efforts increased employability skills the students is through integrating education curriculum [27] [28], make it closer to the college world with the workforce [29], or through the learning process of the students in the classroom [30] [31]. Other strategies that can be done is to optimize the program of career guidance services for students. This is because career guidance program is proven effectively improve employability skills on students in higher education [32] [33]. Career guidance program would be optimized since the program paid attention to students' needs at each level [34].

According to Surya, career guidance becomes one of the programs that are particularly important in the career development for students in Indonesia because the majority of graduates get more preparations on competency which concerns on hard skills (academic skill and vocational skill in the form of knowledge and skills) [35]. However, they are notably weak in the construction of soft skill competencies (personal skills and social skills) such 
as proficiency in self-understanding, confident, rational thinking of responsibility, discipline, willpower, honest, collaborative skills in workplace, values that should be embraced in the workplace, the ability to adapt with the changes. SMK graduates not only master the hard skill, but also they ought to master the soft skill as a proponent of hard skill to be able to work productively, and well-qualified [22]. In addition, the career guidance program can also help students to improve career planning [35] [36], and career maturity [37]. This needs to be conducted by students as an effort to equip them to prepare entering the world of work [38] [39]. Based on the stated background above, the author intends to encourage a study to carry out career guidance program in order to improve employability skills of SMK students.

\section{DISCUSSION}

\subsection{Employability skills}

\subsubsection{Basic concepts of Employability skills}

Robinson explained that employability skills are the fundamental skills needed by someone to seize, retain, and carry out his duties properly, employability skills cover the skills, attitudes, and behaviors that help a person to be able to cooperate with others in their work, as well as being able to adapt to the changing demands of the job [40]. Knight and Yorke proposed employability skills as a skill, understanding and personal attributes that make graduates more likely to get a job and to be successful in their job choices, provide benefits for individuals who own it, work environment, society and any economics [41] [42]. Whereas Sanders and Grib stated that employability skills are characteristics owned by a person who is related to the ability of working and wishes to continue to engage in the activity of the working world [43].

Bloom and Kitagawa in The Conference Board of Canada employability skills explained that employability skills are the generic skills, attitudes and behaviours that are desired by employers against new workers and these skills can be developed through various training programs [44]. Overtoom defined the employability skills as basic skills which represent the essential capabilities and functions in the knowledge, skills, and attitudes essential required by the workforce of the $21^{\text {st }}$ century, as well as necessary for career success at all levels of work and for all levels of education [45]. Weaver and DeLuca et $\mathrm{Al}$ argued employability skills as personal, social, behavioral, and daily living habits which have been identified as being important to the employers and workers who will enter on job entry, employability skills are great life skills to be taught as the necessity of teaching the basic skills [17]. Confederation of British Industry explained that employability skills are the qualities and competence owned by an individual that is required in order to meet the needs of entrepreneurs and customers and is a skill that help to realize the aspirations and potential of individuals at work [46].

In the workforce, employability skills have been widely known despite their naming sometimes differ between one country with another. It is as mentioned by Wilton that the other terms of employability skills is core work skills, both refer to the same sense which is the skills required by the workforce needs to be owned by every individual, men and women, in order to be able to work with a qualified result [47].

National Centre for Vocational Education Research listed various terms of employability skills in some countries. For example in 1) United Kingdom: the core Skills, key skills, general skills, 2) New Zealand: essential skills, 3) Australia: key skills, skills for work, generic skills, 4) Canada: Skills for work, 5) United States: basic skills, important skills, knowledge of how to work, generic skills, 6) Singapore: critical thinking skills, 7) France: skills that can be transferred, 8) Germany: 9 key Qualifications) Switzerland: interdisciplinary Goals, as well as 10) Denmark: independent qualification Process [48].

Some organizations or associations also provide terminology regarding the employability skills, for instance, ASEAN uses the term core work skills; Latin America uses the term Key Competencies, Work Competencies; European Cmsn uses the term Key Competencies; The OECD uses the term Key Competencies; ILO uses the term Core Work Skills/Core Skills for Employability; and EVAGMR uses Transferable Skills [47]. In addition, core skills, key skills, trasnferable skills, general skills, non-technial skills, soft skills, essential skills are some of the similar terms used as employability skills according to NCVER [2].

ILO as an International Labour Organization under the auspices of the United Nations gives a definition about employability skill as a skill, knowledge, and competencies that can improve the ability of employees to survive on their work, develop their career and overcome obstacles they face, and can easily get another job in the workplpace if they are willing to [49]. Further perspective according to ILO employability skills enable individuals to continue to acquire and apply 
new knowledge and skills. For terminology, ILO uses the term core work skills or core skills for employability. A publication of the Confederation of British industry (CBI) in 1998 defined the employability skills as a quality and competencies required to meet the changing needs of employers and customers and with realizing the aspirations and potential of a person [50].

Yorke explained that the employability skills are the skills, understanding, and personal attributes which make the graduates are more likely to get a job and succeeding in the job they choose [51]. Employability skills are generic skills required by all levels of the work type [48]. Bennet mentioned that the greatest challenge faced by the education world nowadays is producing alumni who have the adequate abilities in terms of academic (academic skills), skills mastery (technical skills), and in terms of the ability of employment (employability skills) [25].

On the other hand, according to Pandang argued that employability skills are one of the main skills that become the main consideration of indicators by business owners and company leaders in receiving employees [47]. Employability skills are mainly important because job demand in modern era demands initiative, flexibility, and a person's ability to handle a variety of tasks [25]. Therefore, students need to be suppoerted with a set of skills to achieve success in the professional world [52].

A study in Singapore showed some employability skills that are desired by the industrialized world of the prospective workers [41]. The results of such research shows there are 9 types of employability skills that are particularly needed by the industrialized world. The following lists in sequence starting from the highest to the lowest are, teamwork, problem solving skills, planning skills, emotional labour, Literacy skills, influencing skills, physical skills, Leadership skills, numeracy skills. According to the Australian Chamber of Commerce and Industry (ACCI) and the Business Council of Australia (BCA), employability skills are required not only the skills to get a job, but also to progress within the company so that it can reach someone's potential and contribute successfully on the strategic direction of the company.

From some of the above explanations, it can be concluded that the employability skills are nontechnical basic skills needed by every individual who wish to enter into job entry. These skills become very important because it can support a person's career development activities and in the workplace, not only benefits to the success personally, but these skills can impact for the working environment (companies, offices, establishments) since the employees own these skills.

\subsubsection{The elements of Employability skills}

Robinson divided the employability skills into three elements, as follows; (a) the Basic Academic Skills of these skills such as reading, writing, science, math, oral communication, and listening. (b) Higher-Order Thinking Skills, these skills include learning, reasoning, creative thinking, decision making ability, and problem solving. (c) Personal Qualities, these skills include the attitude of responsibility, self-control, self confidence, social skills, honesty, ability to adapt, have intergrity, punctuality, ability of working in a team, good working attitude, have a purpose in life, eyecatching, cooperative, having self-motivation and self-management [40].

Employability skills according to Hanafi he proposed to divide them into three elements (1) basic skills include reading, writing and calculating; (2) interpersonal skills include communicating and working in a team; and (3) self-attributes such as the ability to learn and how to deal with changes that always occur in the community [25]. Whereas, Yahya has formulated the employability skills into 3 main types, namely: a) academic skills including the ability to resolve the issue, the ability of critical thinking, communication skills, and mathematical abilities; b) personal skills, including the attitude of responsibility, positive attitude, and the ability to adapt; and the third 3) skills in team work, including the ability to cooperate with others, and the ability to be involved in certain projects [45]. While Through cited some employability skills needed by the workplace, such as: team work, leadership, positive attitude, communication, problem-solving, numeracy, cultural sensitivity, commercial [53].

In Malaysia University of Technology, there are seven types of employability skills that become the emphasis for students who will be graduating, such as: a) Communication Skills, b) Team working, c) Problem Solving, d) Adaptability e) Lifelong Learning, f) Self-Esteem, g) Ethics \& Integrity [45]. Gibson \& Mitchell lays out that according to the National Association of Colleges and Employers (NACEWeb) there are 10 primary skills in which they are the most important and mainly needed in the workplace. These skills are: a) communication skills, b) honesty, c) teamwork skills, d) work with ethical, e) analytical skills, f) adaptive skills, g) social skills one to another, h) motivation/initiative; I) computational technology skills, and j) detailoriented [47]. 
Royal Melbourne Institute Of Technology University classifies the employablity skills into 8 basic skills, such as: a) communication, b) teamwork, c) problem solving, d) self-management, e) planning and organising, f) technology, g) learning, dan h) initiative and enterprise [54].

On the other hand, Science, Technology, Engineering, and Mathematics Network released the 10 kinds of employability skills that are the most important to be owned by someone and putting them together in sequence. These 10 important skills are as follows: a) Communication and interpersonal skills, b) problem solving skills, c) using your initiative and being self-motivated, d) working under pressure and to deadlines, e) organisational skills, f) team working, g) ability to learn and adapt, h) numeracy, i) valuing diversity and difference, and $\mathrm{j}$ ) negotiation skills [55].

Business Council of Australia split the employability skills into eight types of skills required in the areas of ICT and financial jobs. Those eight kinds of skills are: a) the skills of communicating, b) thinking skills, c) learning skills, d) skills to manage in projects and priorities, e) skills in collaboration and understanding systems, f) skill in applying and using technology, g) leadership skills, h) and personal and interpersonal skills [48].

Hermana and Muhafidin outlined that employability skills have three (3) derivatives as part of these skills are: (1) basic skills (2) high level thinking skills (3) characters and affective skills [52]. Furthermore, according to Hermana and Muhafidin, the basic skills consist of proficiency to communicate verbally, either speaking or listening), reading well so that they can understand and follow the reading thinking, mastery of the basics of numeracy, and skilled in writing [52]. In contrast, the high level thinking skills include problem solving, strategy and skills learning, innovative and creative thinking, as well as the ability to make decisions. The third is the affective skills that include responsibility, positive attitude toward works, honest, careful, thorough, and efficient, interpersonal relationships, cooperation, and team work, confident and have a positive attitude towards ourselves, adaptability and flexible, full of enthusiasm and motivation, discipline and selfcontrol, dress up and good appearance, honest and have integrity, and able to work independently without supervision. In 2006, The University of Sydney Careers Centre released eight kinds of employability skills. This was based on the research conduced by Departement of Education, Employment and Workplace Relations. Those eight kinds of skills were a) Communication Skills, b)
Teamwork Skills, c) Problem Solving Skills, d) Initiative \& Enterprise Skills, e) Planning \& Organising Skills, f) Learning Skills, g) Technology Skills, h) Self Management Skills [56].

International Labour Organization under the auspices of the United Nations (UN) released various types of employability skills gained after obtaining 63 types of studies on employability skills, and concluded the kinds of employability skills into 3 fundamental basics [47], which were as follows:

- Basic skills: communication.

- Thinking skills: problem solving and innovative thinking.

- Affective Skills: responsibility, positive attitude toward work, efficiency, interpersonal skills, work as a team, confident, positive self-image, adaptability, flexibility, enthusiasm, motivation, discipline, self management, neat, honesty, integrity, and ability to work without supervision.

Some examples conducted in schools in order to improve the ability of students' skills are by teaching skills through scientific approaches [25], for instance chemistry learning based on media ICT [57], applied mathematics learning by Problem Based Learning approach [58] or also by inviting keynote speakers to give an introduction on the workplace to the students [59]. In this respect, the improvement of employability skills related to linguistic competence can be done through the use of film [60].

\subsection{Career Guidance}

\subsubsection{Concepts of Career Guidance}

The implementation of guidance and counseling in school aims to help students to achieve the goals set out in three aspects of one's life that includes personal aspects-social, academic, and career [61]. These 3 carried out areas should have been a concern for teachers of guidance and counseling at every level of education. From the purposes cited by Suherman this should be realized that career guidance is one of the essential services to optimize its implementation in school as part of the attainment efforts of guidance and counseling [61].

According to Suherman, there were seven purposes of the program guidance implementation on the career aspect expected to be owned by students, they were as follows: a) able to understand the condition of the State of the environment positively and able to conform in accordance with embraced norms individually, b) have a commitment 
to seriously implement the values of divinity in their career, c) have an attitude of tolerance toward others, d) able to show respect to career success and the kinds of career of other employees, and do not underestimate them, e) have an understanding and a positive attitude, objective, and constructive to the career challenges faced, f) able to make a decision appropriately in their career life, and g) able to kindly interact in social in form of friendship and brotherhood of fellow workers [61].

Supriatna and Ilfiandra laid out the notion of career guidance as follows: "career guidance is a relief process, service, approach to the individual to be able to recognize and understand themselves, get to know the workplace, plan for the future that corresponds to a satisfactory life term, are able to determine accurately, and take decisions and responsible for the taken decisions so that they enable to manifest themselves meaningfully. " [62]

Career guidance is a series of relief efforts against the individuals in order to have the ability to understand themselves and the workplace, as well as being able to develop future plans according to what we expect [63]. In addition, according to Sukardi career guidance is a self-preparation effort to confront in the workplace, including study of the series of skills in order to be able to choose a particular type of work and have the ability to adapt to the type of work that is practiced [38]. Walgito proposed a definition of guidance as an aid or help granted to an individual or more than one individual to overcome various hardships in their life and so that individuals can reach their prosperity [64].

Surya explained that career guidance program became one of the urgent matters in the career development for students in Indonesia [35]. That statement is based upon several considerable ideas, such as: a) the unemployment number is still high, b) There is still dichotomy in society between the prestigious jobs and not prestigious jobs. Not to mention, there is still a presumption that working in a farm is lower than employees, c) There will appear a lot of SMK graduates that would result on middle employees with certain skills, but there are still many who have not obtained a standard of competences, d) Educational graduates mostly master theoritical knowledge but highly less in practice experiences, e) graduates are more equipped with the hard skills competencies (academic skill and vocational skill in form of knowledge and skills), however, they are still weak in the construction of soft skill competencies (personal skills and social skills) include: proficiency to have self-recognition, confident, rational thinking of responsibility, discipline, willpower, honest, team work skills, values that should be embraced in the works, the ability to adapt with any changes, etc, f) There are still many employees who just concern to the living needs, not for happiness and benefitial for themselves and life community as well as the environment, g) most people still pursue a career that is linear, h) the students choose higher education, and their focus in College has not been based on a clear career orientation.

Concrete career problems felt by students according to Supriatna include: a) the students have an understanding of the right way to choose program study that matches with mastered skills and interests, b) students do not have enough information about the workplace, c) students are confused in choosing jobs, d) students are less able to choose jobs that suit into their abilities and interests, e) students feel anxious to get a job after completing education, $\mathrm{f}$ ) students do not have clear choice in ther target universities if wish to continue education to College, as well as g) students have not got an overview of the characteristics, future prospects, and the different requirements needed to this type of work that they will involve in [35].

\subsubsection{The implementation Principles of Career Guidance}

In conducting career guidance service, it absolutely received considerable attention to note some principles in order to make the implementation of career guidance run optimally. According to Supriatna and Ilfiandra the implementation of career guidance needs to have attention in the following principles [62]:

- Career Guidance is a continuity process in the entire life of a person, not a disaggregated event to one another. Thus, career guidance is a series of someone's life associated with all aspects of growth and development which they are dealing with.

- Career Guidance aims for all individuals without exception. However, in practice, the priorities of service can be provided especially for those who is in need of service. The priority scale given by considering the levels of problem and whether the problem is crucial to be solved. And thus, career guidance services provided for all students, then the granting of career guidance services should more emphasis with preventivedevelopmental method.

- Career Guidance is the assistance provided to individuals who are in the developing process. Thus the characteristics of the development of 
specific phases should be the basic consideration in any career guidance activities.

- Career Guidance is based on the individual ability to determine their choices. Every individual has the right to make choices and decisions, but it should be conducted responsibly for any consequences of those choices/decisions. This means that career guidance not only pays attention to the right of the individuals to determine and decide their own choices, but also helps individuals to develop ways of fulfillment choices or that decision responsibly.

- The selection and adjustment career begins with the knowledge of our ownself. This means that individuals need to understand in advance the capabilities that exist in themselves, such as talents, interests, values, needs, work/study achievements and personality.

- Career Guidance helps individuals to understand the workplace and the number of jobs that existed in the community as well as the various sides of their life.

\subsubsection{The implementation objectives of Career Guidance}

The implementation of guidance and counseling in school aims to help students to achieve the goals set out in three aspects of one's life that includes personal aspects-social, academic, and career [61]. These 3 carried out areas should have been a concern for teachers of guidance and counseling at every level of education. From the purposes cited by Suherman this should be realized that career guidance is one of the essential services to optimize its implementation in school as part of the attainment efforts of guidance and counseling [61].

According to sukardi the purpose of implementation of career guidance was divided into two terms called as general purpose and special purpose [38]. Whereas the purpose of the implementation of career guidance according to Sukardi is helping students to have a good and thorough understanding of themselves and their environment, in order to be able to make planning, choosing activities, and take decisions against the career and way of life that gives a sense of satisfaction for themselves and their environment [38]. Otherwise, the specific purposes of career guidance according to Sukardi were as follows:
- Students can improve and understand their knowledge about themselves (self-concept). Self-understanding is self-image. This later as the initial step in determining the direction to choose the right career for students so that this would create the existence of independence stance in choosing a career that fits into their self-understanding.

- Students can improve their knowledge of workplace. An understanding of the workforce includes an understanding of the various information requirements of acceptance in the workplace, the content and nature of an employment, job situation including in social aspects, physical, administrative, the job future, its organization, as well as lifestyle in the company.

- Students can develop attitudes and values themselves in the face of employment choices and face obstacles that may arise caused by themselves and environmental factors, as well as seeking a way to overcome these barriers.

- Students can improve their thinking skills thus they will be able to take a decision about the position that suits them and is available in the workplace. Through career guidance, students will be directed in getting to know themselves and their ability to understand oneself and always able to improve their abilities, trained in planning their career and thus students become trained and mature in thinking and planning their career.

- Students can master the basic skills that are essential in the work, especially the ability to communicate, cooperate, initiative and so on.

Career guidance services program to develop SMK students' employability skills is very possible to be given because this term of program proves effectively to improve employability skills on students in higher education [32] [33].

\subsection{Optimization of Career Guidance to enhance SMK students' Employability Skills}

Guidance and counselling as one spirit in education need to constantly strive to provide an optimal contribution in advancing education of the nation. Guidance and counselling have to focus on three domains (academic, personal/social, and career) and have a big responsibility in raising the quality of education in the country. Moreover, the national challenge in the near future might be 
heavier seeing the the quality of education in Indonesia still lags behind some other neighboring countries. This can be seen from Indonesia education quality index released by the OECD (Organization for Economic and Development) puts educational quality of Indonesia in number 69 from 76 countries, below some other ASEAN countries such as Singapore, Vietnam, Malaysia, and Thailand [65].

It has been previously described that employability skills are the basic needed skills to enter the workforce. Employability skills have been much discussed at the college level, as well as the implementation of guidance career in an effort to enhance employability skills. Furthermore, career guidance program in college is proven to give a good contribution and influence in improving the students employability skills [32] [33]. Career guidance will be more effective and optimum if the given career guidance program linked to the students need at the highest level respectively [34].

In the context of Indonesia, vocational secondary education is a part of education level that also needs to get a good understanding of employability skills. Students in vocational schools are important to understand those skills kindly on what sort and how to comprehend them. With a good understanding of employability skills, the students and graduates who come from vocational school education will receive information and raise their awareness to improve fundamental skills needed once they plan to enter into job entry. This provision is notably important thing, mainly fundamental and inseparable from the goals of SMK's existence, such as to prepare skilled generations that have skills and competency of work.

Guidance and counseling role should be optimized by the school in order to acquaint students with the workplace. The given introduction is not just the name and ways that need to be conducted for a particular career. However, it concerns towards introducing every detail important information and mandatory skills which need to be owned to compete in the workforce. On the other hand, the students are also given career guidance program gardually and sustainably in accordance with the grade levels, for each class and levels have different needs related to career and the workplace. It is also in line with the principles of organization of career guidance expressed by Supriatna and Ilfiandra [62]. The optimization of the services of guidance and counselling to improve understanding of employability skills of students and other career insights can be performed with a wide variety of approaches.

Guidance and counseling can also bring the guest speakers who are the practitioners of the workforce so that students get direct experience learning interactively and provide them information and knowledge about what, how, and why of employability skills into something very important in the workplace [59]. Another thing that is not less important is to develop a module of career guidance that can be used by students to get information and more specific knowledge that they increasingly have the ability of good career decisions [65] as well as have the ability to prepare for a career that they will enter in job entry [36].

\section{CONCLUSION}

It cannot be denied that education has a very tight relationship with workplace, even the process of education run by someone is one of the efforts to achieve success in their career in the world of work. This kind of awareness will certainly affect the efforts of optimization of the educational efforts carried out, both on the formal and non-formal level, to make process and output generated by the education can provide great benefits for the success of students. Career guidance program as one of the components of education is necessary to take the role optimally in order to provide a good understanding to students about careers and the world of work. In addition the program of career guidance is necessary to always accompany and direct students to have awareness and good planning dealing with the planning career options that they will select. All of these processes require the totality and the seriousness of the whole staffs of guidance and counseling. Among the kinds of seriousness that can be done is to prepare a planned and measurable career guidance program at every level of the class and level of education. In addition, it also needs career guidance modules that can be used in the service of career guidance for vocational high school (SMK) students and function as providing a guideline in the implementation of SMK career guidance.

\section{REFERENCES}

[1] S. Jayaram and M. Engmann, "Developing skills for employability at the secondary level: Effective models for Asia," Prospects, vol. 44, no. 2, pp. 221-233, 2014.

[2] I. M. Suarta, "Hubungan sistem pembelajaran, lingkungan belajar, konsep diri dan pengembangan," J. Penelit. dan Eval. Pendidik., pp. 24-41, 2010.

[3] M. Khare, "Employment, Employability and Higher Education in India: The Missing Links," High. Educ. Futur., vol. 1, no. 1, pp. 39-62, 2014. 
[4] D. Jackson, "Business undergraduates' perceptions of their capabilities in employability skills," Ind. High. Educ., vol. 26, no. 5, pp. 345-356, 2012.

[5] K. Matsouka and D. M. Mihail, "Graduates employability: What do graduates and employers think?," Ind. High. Educ., vol. 30, no. 5, pp. 321-326, 2016.

[6] A. B. Guzman and K. O. Choi, "The relations of employability. skills to career adaptability among technical school students," J. Vocat. Behav., vol. 82, no. 3, pp. 199-207, 2013.

[7] M. C. Abas and O. A. Imam, "Graduates , Competence on Employability Skills and Job Performance," Int. J. Eval. Res. Educ., vol. 5, no. 2, pp. 119-125, 2016.

[8] A. R. A. Djamaris, "Analisis Faktor Kompetensi Soft Skills Mahasiswa yang Dibutuhkan Dunia Kerja Berdasarkan Persepsi Manajer dan HRD Perusahaan,” J. Manaj., vol. XVII, no. 2, pp. 160-174, 2013

[9] J. Sung, M. C. M. Ng, F. Loke, and C. Ramos, "The nature of employability skills: Empirical evidence from Singapore," Int. J. Train. Dev., vol. 17, no. 3, pp. 176-193, 2013.

[10]A. Zaharim, Y. Yusoff, and M. Omar, "Engineering Employability Skills Required By Employers In Asia," Proc. 6th WSEAS Int. Conf. Eng. Educ. Eng., vol. 6, no. 9, pp. 195201, 2009.

[11]A. J. Patandean, "Keterampilan Generik Sains untuk Membangun Karakteristik Siswa," J. Sains dan Pendidik. Fis., vol. 7, no. 1, pp. 7379, 2011.

[12]D. A. Sudjimat, "Kecakapan Kemampu-kerjaan siswa SMK Bertaraf Internasional dan Pengembangannya dalam Pembelajaran," J. Ilmu Pendidik., vol. 17, no. 4, pp. 279-286, 2011.

[13] Wagiran, "The Importance of Devloping Soft Skills in Preparing Vocational High School Graduates," Seameo Voctech, 2008.

[14] M. Y. Husain, S. B. Mokhtar, A. A. Ahmad, and R. Mustapha, "Importance of employability skills from employers' perspective," Procedia Soc. Behav. Sci., vol. 7, no. 2, pp. 430-438, 2010.

[15] S. Sermsuk, D. Triwichitkhun, and S. Wongwanich, "Employment Conditions and Essential Employability Skills Required by, Employers for Secondary School Graduate," Procedia - Soc. Behav. Sci., vol. 116, pp. 18481854,2014

[16]F. Suleman, "Employability Skills of Higher Education Graduates: Little Consensus on a Much-discussed Subject," Procedia - Soc. Behav. Sci., vol. 228, no. June, pp. 169-174, 2016.

[17]M. K. Al-alawneh, "Measuring Students $\hat{a} €^{\mathrm{TM}}$ Employability Skills as They Are Perceived at Yarmouk," Can. Soc. Sci., vol. 10, no. 1, pp. 10-20, 2014.

[18] S. Rosenberg, R. Heimler, and E.-S. Morote, "Basic employability skills: A triangular design approach," Educ. + Train., vol. 54, no. 1, pp. 720, 2012 .
[19] J. Argos and P. Ezquerra, "Universities and Skills for Employability," Procedia - Soc. Behav. Sci., vol. 139, pp. 290-296, 2014.

[20]D. Jackson, "Employability skill development in work-integrated learning: Barriers and best practice," Stud. High. Educ., vol. 40, no. 2, pp. $350-367,2015$

[21] D. Jackson and D. Jackson, “Testing a model of undergraduate competence in employability skills and its implications for stakeholders," J. Educ. Work, no. August, pp. 37-41, 2014.

[22]D. Suryanto, W. Kamdi, and Sutrisno, "Relevansi soft skill yang dibutuhkan dunia usaha/industri dengan yang dibelajarkan di sekolah menengah kejuruan," Teknol. DAN Kejuru., vol. 36, no. 2, pp. 107-118, 2013.

[23] S. S. Weligamage, "Graduatese Employability Skills: Evidence from Literature Review," Asaihl, pp. 115-125, 2009.

[24]A. R. Madar and Y. Buntat, "Elements of employability skills among students from Community Colleges Malaysia," J. Tech. Vocat. Eng. Educ., vol. 4, no. December, pp. 1-11, 2011.

[25] Sunardi, Purnomo, and E. Sutadji, "Pengembangan Employability Skill Siswa SMK Ditinjau dari Implementasi Pendekatan Saintifik,"J. Pendidik., vol. 1, no. 7, pp. 13911398, 2016.

[26] I. Hanafi, "Re-Orientasi Keterampilan Kerja Lulusan Pendidikan Kejuruan," J. Pendidik. Vokasi, vol. 2, no. 1, pp. 107-116, 2012.

[27] V. Saunders and K. Zuzel, "Evaluating Employability Skills: Employer and Student Perceptions," Biosci. Educ., vol. 15, no. 1, pp. $1-15,2010$.

[28] P. S. Aithal, M. S. Kumar, and P. Kumari, "Methods and Approach for Employability Skill Generation in Higher Educational Institutions," Int. J. Manag. IT, Eng., vol. 5, no. 7, pp. 390$410,2015$.

[29] S. Eden, "Out of the comfort zone: enhancing work-based learning about employability, through student reflection on work placements," J. Geogr. High. Educ., vol. 38, no. 2, pp. 266$276,2014$.

[30] J. Sudirwan and H. Pangestu, "Kesiapan Dosen Untuk Mengembangkan Keterampilan Kerja, Studi Kasus pada Binus University," Semin. Nas. Teknol. Inf. dan Komun. 2015 (SENTIKA 2015), vol. 2015, no. Sentika, pp. 344-354, 2015.

[31]Rusydan, "Mengintegrasikan Soft Skill Dalam Pembelajaran Interaktif,” J. Hum., vol. 1, no. 2, 2013.

[32] S. Buchori and Ilfiandra, "Efektivitas Bimbingan Karier Untuk Peningkatan Core Work Skills Mahasiswa," J. Psikol. Pendidik. Konseling, vol. 1, no. 1, pp. 2443-2202, 2015.

[33] A. M. Pellicer, A. L. Botía, and M. B. G. Palma, "Career Guidance in Universities as a Tool for the Improvement of Employability. The Case of the University of Murcia," Procedia - Soc. Behav. Sci., vol. 139, pp. 56-64, 2014. 
[34] S. Chircu, "Career Counseling Needs for Students - A Comparative Study," Procedia Soc. Behav. Sci., vol. 127, pp. 549-553, 2014.

[35] I. Juwitaningrum, "Program Bimbingan Karir Untuk Meningkatkan Kematangan Karir Siswa SMK," Psikopedagogia, vol. 2, no. 2, pp. 388421,2013

[36] T. T. Atmaja, "Upaya Meningkatkan Perencanaan Karir Siswa Melalui Bimbingan Karir dengan Penggunaan Media Modul,' Psikopedagogia, vol. 3, no. 2, pp. 57-66, 2014.

[37]H. Budisiwi, "Model Bimbingan Karir Holland Untuk Meningkatkan Kematangan Pilihan Karir Siswa," Cakrawala J. Pendidik., vol. 7, no. 11, 2013.

[38] S. R. Abubakar, "Pelaksanaan Bimbingan Karir Bagi Siswa SMA Sebagai Persiapan Awal Memasuki Dunia Kerja," Selami IPS, vol. 1, no. 34, pp. 137-144, 2011.

[39] M. Fransiska, I. M. Yudana, and N. Natajaya, "Kontribusi Praktek Kerja Industri, Bimbingan Karir Kejuruan, dan Ekspektasi Karir terhadap Kompetensi Kejuruan (Studi Pada Mahasiswa Jurusan Tata Boga Undhira Bali)," J. Penelit. Pascasarj. Univ. Pendidik. Ganesha, vol. 4, no. 1, 2013.

[40] J.P. Robinson. What Are Employability Skills?. The Workplace volume 1 issue 3 September 15, 2000.

[41] The ESECT (Enhancing Student Employability Co-ordination Team). Pedagogy for employability, Learning and Employability Series one. Heslington York: The Higher Education Academy. 2006.

[42]D. Cole, M. Tibby. Defining and developing your approach to employability, A framework for higher education institutions. Heslington York: The Higher Education Academy. 2013.

[43] Sumarno. Employability Skills dan Pengaruhnya Terhadap Penghasilan Lulusan SMK Teknologi dan Industri. Jurnal Kependidikan Tahun XXXVIII Nomor I Mei 2008.

[44] M. R. Bloom, K.G. Kitagawa. Understanding Employability Skills. The Confrence Board of Canada. 1999.

[45]B.Yahya. Kemahiran "Employability" (Soft Skills) dan Kepentingan Penerapannya di Kolejkolej Kediaman Pelajar. Online From: http://eprints.utm.my/135/. 2006.

[46] R. W. McQuaid and C. Lindsay, - The Concept of Employability,\| Urban Stud., vol. 42, no. 2, pp. 197-219, 2005.

[47] Buchori, Sahril. Program Bimbingan Karier Untuk Peningkatan Core Work Skills Mahasiswa. Tesis: Universitas Pendidikan Indonesia. Bandung. 2015. Unpublished

[48] W. Widido. Tinjauan tentang Keterampina Generik. Online From: https://vahonov.files.wordpress.com/2009/07/tin jauan-tentang-keterampilan-generik.pdf. 2009. Unpublished
[49]L. Brewer.. Enhancing youth employability: What? Why? and How? Guide to core work skills. Geneva: International Labour Office, Skills and Employability Department. 2013.

[50]D. Turner. Employability skills development in the United Kingdom. Kensington Park: National Center for Vocational Education Research (NCVR). 2002.

[51]K. Lowden, S. Hall, D. Elliot, \& J. Lewin. Employers' perceptions of the employability Intelligenc skills of new graduates. London: Edge Foundation. 2011.

[52]H. D. Hermana and D. Muhafiddin, - Life Skills dan Pasar Kerja, 2009.

[53]F. Trough. Brilliant Employability Skills. Second Edition. New York: Pearson Education. 2017.

[54]Royal Melbourne Institute of Technology University. Quick tips Employability Skills. Online. From: http://mams.rmit.edu.au/ mlad83koqygu.pdf. 2015.

[55] Science, Technology, Engineering, and https://www.exeter.ac.uk/ambassadors/HESTE $\mathrm{M} /$ resources/General/ STEMNET\%20Employability\%20skills\%20gui de.pdfSunardi. 2009.

[56] The University of Sydney Careers Centre. Identifying Your Employability Skills. Online. From: https://sydney.edu.au/careers/careeradvice/downloads/id emp_skills.pdf. 2006.

[57] S. Mulyani, M. N. Hana, and E. Nursa, -Improving Students ' Generic Skill In Science Through Chemistry Learning Using IctBased Media On Reaction Rate And Osmotic Pressure Material,\| J. Pendidik. IPA Indones., vol. 5, no. 1, pp. 150-156, 2016.

[58]H. Othman, Y. Buntat, and A. Sulaiman, -Applied Mathematics cans Enhance Employability Skills Through PBL,\| Int. Confrence Math. Educ. Res. 2010 (ICMER 2010), vol. 8, no. 5, pp. 332-337, 2010.

[59]L. Riebe, R. Sibson, D. Roepen, and K. Meakins, - Impact of industry guest speakers on business students' perceptions of employability skills development, $\|$ Ind. High. Educ., vol. 27, no. 1, pp. 55-66, 2013.

[60]S. Daly, -Enhancing employability skills through the use of film in the language classroom,\| Lang. Learn. J., vol. 44, no. 2, pp. 140-151, 2013

[61] Suherman, U. Bimbingan dan Konseling Karir: Sepanjang Rentang Kehidupan. Bandung: Rizqi Press. 2013.

[62]M. Supriatna, Ilfiandra. APA DAN BAGAIMANA BIMBINGAN KARIER. Materi Sajian Workshop Bimbingan dan Konseling Politeknik Kesehatan, Tasikmalaya 22-25 Maret 2006. Unpublished

[63] A. Juntika, Y. Syamsu. Landasan Bimbingan dan Konseling, Bandung: PT. Remaja Rosdakarya. 2010.

[64]B. Walgito...Bimbingan Dan Konseling (Studi Karier). Yogyakarta: Andi. 2010. 
[65]T. Supatmi, "Pengembangan Bahan Informasi Bimbingan Pemilihan Karir untuk Meningkatkan Kemampuan Pengambilan Keputusan Karir Siswa SMK Rumpun Jurusan Ekonomi," Consilium, vol. 1, no. 2, 2013. 